\title{
Ayurvedic Management of Kitibha Kushta w.r.t. Guttate Psoriasis- A Single Case Study
}

\author{
Case Report
}

\section{Vishakha Shashikant Bindalkar1*, Vinod Ade², Saurabh Deshmukh³}

1. Post Graduate scholar, 2. Professor, 3. Assistant Professor, Department of Kayachikitsa, Mahatma Gandhi Ayurveda College, Hospital and Research Center, Salod (H) Wardha.

\begin{abstract}
Guttate psoriasis is a type of psoriasis that presents over the upper trunk and proximal extremities, it is small ( 0.5 to $1.5 \mathrm{~cm}$ in diameter) lesions; it is found frequently in young adults. As per its clinical features we will compare with Kitibha Kushta. The life time prevalence is approximately $2 \%$ of individuals with psoriasis. Many treatment modalities have been adopted in medical sciences, but it is having various side effects. So here in this case by using Shodhan, Shaman and Bahirparimarjan chikitsa we successfully treated the case of Kitibha kushtha. It is a single case study, A 22 year male patient approached to Kayachikitsa OPD having complaint of multiple small red lesions over the chest, abdomen, and back region also on both upper limbs and Itching over them since 2 years. The patient was treated with Shodhan and Shaman Chikitsa. Patient got 90\% result in chief and associated complaints and during and after the completion of therapy there is improvement in the quality of life of the patient. After Shodhana and Shaman Chikitsa patient got satisfactory relief in symptoms.
\end{abstract}

Key Words: Guttate Psoriasis, Kitibha kushta, Shodhan, Shaman, Bahirparimarjan chikitsa.

\section{Introduction}

Guttate psoriasis ( Also known as eruptive psoriasis) is a type of psoriasis that presents as small ( 0.5 to $1.5 \mathrm{~cm}$ in diameter) lesions over the upper trunk and proximal extremities; it is found frequently in young adults. $(1,2)$ The term "guttate" is used to described the drop like appearance of skin lesion. Guttate psoriasis is classically triggered by a bacterial infection, strongly associated with a streptococcus bacterium and typically occurs 1-2 weeks after an episode of tonsilitis; usually an upper respiratory tract infection. (3) Guttate psoriasis can affect any area of skin and appears as little red blisters that are tear drop in shape. This type of psoriasis accounts for about $2 \%$ of individuals with psoriasis. Current research is limited in identifying the best treatment for guttate psoriasis. Commonly used regimens include topical tar and UVB phototherapy, anthralin and topical steroids. (4)

In Ayurved all types of skin diseases are included under the Kushtha. Acharya charak mentioned it in Ashtamahagad (difficult to treat).(5) Acharya charak described kushtha rogadhikar in which he classified Kushtha in to two major types; Mahakushtha (Major skin diseases) and Kshudra kushtha

\section{* Corresponding Author:}

\section{Vishakha Bindalkar}

PG scholar, Department of Kayachikitsa,

Mahatma Gandhi Ayurved College Hospital and

Research centre,

Salod(H), Wardha..

Email id - vishakha.bindalkar@gmail.com
(Minor skin diseases).(6) Kitibha kustha is one of the type of the Kshudra kushtha, which is having Lakshanas like Shyava, Kina, Khara sparsha, Parusha, Ruksha pidika and kandu.(7) Kitibha kushtha is having predominance of Vata and Kapha dosha, which are having lakshanas of the individual doshas. Kitibha kushtha manifests due to vitiation of Sapta dhatus, they are Tridosha, Twak, Rakta, Mamsa and Lasika. In samhitas, according to the Bala, Dosha and Vyadhi avastha Shodhan and Shaman Chikitsa is described for the Kushtha. Repeated shodhan is indicated in Kushtha due to Bahu doshavastha, to eliminated the aggrevated doshas which helps to treat the root cause of disease. So here a case of Kitibha kushtha is successfully treated with Vaman, Virechan and Shaman Chikitsa.

\section{Case report}

A 22 years male patient came with chief complaint of multiple small red lesions over the chest, abdomen, back region also on both upper limbs and Itching over them since 2 years.

\section{Present History}

Patient was well before two years, after that he started complaining of small red blisters like lesion over the abdomen and itching over it, gradually it increased and spread all over the abdomen, chest, back region and both upper limbs along with itching. The patient took allopathy medications for above complaints, but he did not get satisfactory relief, so he came to Mahatma Gandhi Ayurved College, Hospital and Research Center, Salod $(\mathrm{H})$ Wardha for further treatment. 
Vishakha Shashikant Bindalkar et.al., Ayurvedic Management of Kitibha Kushta w.r.t. Guttate Psoriasis- A Single Case Study

Patient had recurrent history of Tonsillitis. No any family history was present regarding psoriasis or any dermatological disorders. Disturbed sleep due to the itching and there is lack of appetite. Ashtavidha Pariksha was within normal limit but only mala was asamyak due to irregular bowel habits, jivha was saam and sparsha was kina khara sparsha and parusha with ruksha pidika. On Examination, all vitals of the patient were within normal limit. Pulse rate 80 permin regular and vata pittaj, Blood pressure was $130 / 80 \mathrm{mmHg}$. Respiratory rate was 18 per min, temperature was $98^{\circ} \mathrm{f}$.

\section{Examination of Skin}

A.Inspection

- Size shape - Erythematous small lesions over abdomen, chest, back region and both upper limbs.

- Color - Red

- Thickness -0.8 to $1.2 \mathrm{~mm}$ thick

- Lesion - Small red blisters like lesion.

- Palpation :-

- Moisture- Dryness

- Temperature - Warmth to touch
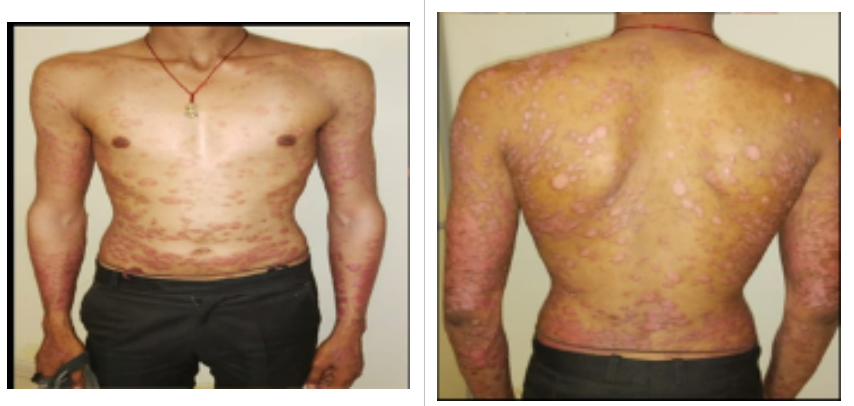

Picture no. 1: Small red blisters like lesion over abdomen, chest, back region and both upper limbs.

Diagnosis

Kitibha kushtha (Guttate Psoriasis)

\section{Treatment Plan given}

- Shodhan- Vaman,Virechan.

- Shamana aushadhi along with Bahirparimarjan chikitsa for 4 months in three follow up.

- Texture - Rough

Table no.1:- Shodhan chikitsa - by following the purvakarma, pradhankarma and pschyat karma.

\begin{tabular}{|c|c|c|c|c|}
\hline Procedure & Medicine & Dose & Duration & Route \\
\hline Deepan pachan & Trikatu churna & $\begin{array}{l}3 \text { gm bd before } \\
\text { meal with luke } \\
\text { warm water }\end{array}$ & for 3 days & Oral \\
\hline Snehapana & Panchatikta ghrita & $\begin{array}{l}\text { Starting from the } \\
\text { 30ml in the } \\
\text { increasing order } \\
\text { upto the } 180 \mathrm{ml} \text {. } \\
\text { (empty stomach at } \\
\text { morning time with } \\
\text { lukewarm water) }\end{array}$ & For 7 days & Oral \\
\hline $\begin{array}{l}\text { Sarvanga } \\
\text { abhyanga } F / B \\
\text { nadi swedan }[8]\end{array}$ & $\begin{array}{l}\text { Marichyadi tail } \\
\text { F/B Bashpaswed }\end{array}$ & Quantity sufficient & $\begin{array}{c}\text { For } 2 \text { days } \\
\text { (After completion } \\
\text { of } 7 \text { days of } \\
\text { snehapan) } \\
\end{array}$ & $\begin{array}{l}\text { External } \\
\text { application }\end{array}$ \\
\hline $\begin{array}{c}\text { Vamana } \\
\text { (F/B sansarjan } \\
\text { karma for } 5 \text { days })\end{array}$ & Madanphalyoga & $\begin{array}{l}\text { Antarnakha } \\
\text { mushthi matra }\end{array}$ & $\begin{array}{l}\text { For } 1 \text { day (at } \\
\text { morning time after } \\
\text { snehan and swedan }\end{array}$ & Oral \\
\hline $\begin{array}{c}\text { Virechan } \\
\text { (F/B sansarjan } \\
\text { karma for } 5 \text { days })\end{array}$ & $\begin{array}{l}\text { Haritaki churna + } \\
\text { Kutaki churna / } \\
\text { each } 25 \mathrm{gm} \\
\text { (Prepare kwath), } \\
\text { Abhayadi modak }\end{array}$ & $\begin{array}{l}\text { Prepare kwath as } \\
\text { per sharangdhar } \\
\text { samhita } \\
2 \text { tablets with luke } \\
\text { warm water }\end{array}$ & $\begin{array}{l}\text { For } 1 \text { day after } \\
\text { following } \\
\text { purvakarma } \\
\text { procedure (after } 5 \\
\text { months) }\end{array}$ & Oral \\
\hline
\end{tabular}

\section{Paschyat Karma}

After obtaining Samyaka Vamana Lakshana and Samyaka Virechana Lakshana Dhoomapan was given with stick made of Aguru for 5 minutes by each nostril. Then patient was advised to follow the Sansarjana Karma for five days. Sansarjana Karma [9] was given in the form of Peya, Vilepi, Akrita Mudga Yusha, Krita Mudga Yusha for 5 days. 
International Journal of Ayurvedic Medicine, Vol 11 (1), 136-142

\section{Shaman aushadhi and Bahirparimarjan chikitsa}

Table no. 2:- 1st follow up

\begin{tabular}{|c|c|c|c|c|}
\hline Medicine & Dose & Anupan & Route & Duration \\
\hline Arogyavardhini vati & $\begin{array}{c}250 \mathrm{mg} \mathrm{BD} \text { after } \\
\text { meal }\end{array}$ & Luke warm water & $\begin{array}{c}2 \text { months } \\
\text { an interval of 7 } \\
\text { days })\end{array}$ \\
\hline Manibhadra guda & 10 gm BD after meal & Luke warm water & Oral & 2 months \\
\hline Vetapallai oil & $\begin{array}{c}\text { Quantity sufficient } \\
\text { After bath }\end{array}$ & - & External application & 1 month \\
\hline Atrisor cream & After bath & - & External application & 2 months \\
\hline
\end{tabular}

Table no. 3:- 2nd follow up Shaman

\begin{tabular}{|c|c|c|c|c|}
\hline Gandhak rasayan & $\begin{array}{c}250 \mathrm{mg} \text { TDS after } \\
\text { meal }\end{array}$ & Luke warm water & Oral & 2 months \\
\hline 777 oil & $\begin{array}{c}\text { Q.S. } \\
\text { At night }\end{array}$ & - & External application & 2 months \\
\hline Atrisor cream & $\begin{array}{c}\text { Q.S. } \\
\text { After bath }\end{array}$ & - & External application & 2 months \\
\hline
\end{tabular}

Table no. 4:- 3rd follow up Shaman

\begin{tabular}{|c|c|c|c|c|}
\hline Raktashodhak vati & $\begin{array}{c}125 \mathrm{mg} \text { TDS after } \\
\text { meal }\end{array}$ & Luke warm water & Oral & 2 months \\
\hline 777 oil & Q.S. At night & - & External application & 2 months \\
\hline Atrisor moisturizer & Q.S. After bath & - & External application & 2 months \\
\hline
\end{tabular}

\section{Grading - PASI (Psoriasis Area Severity Index) Score}

Within each area, the severity is estimated by three clinical sings: Severity parameters are measured on the scale of 0 to 4, from none to maximum. The body is divided into four sections [head (H) (10\% of a person's skin); arms (A) (20\%): trunk (T) (30\%); legs (L) (40\%)]. Each of this area is scored by itself, and then the four scores are combined into the final PASI. For each section, the percent of area of skin involved, is estimated and then transformed into a grade from 0 to 6 .

Table no. 5: Showing area involved with grading

\begin{tabular}{|c|c|}
\hline $0 \%$ of involved area & Grade: 0 \\
\hline$<10 \%$ of involved area & Grade: 1 \\
\hline $10-29 \%$ of involved area & Grade: 2 \\
\hline $30-49 \%$ of involved area & Grade: 3 \\
\hline $50-69 \%$ of involved area & Grade: 4 \\
\hline $70-89 \%$ of involved area & Grade: 5 \\
\hline $90-100 \%$ of involved area & Grade: 6 \\
\hline
\end{tabular}

Table no 6: Showing assessment criteria

\begin{tabular}{|c|c|c|c|c|c|c|c|c|}
\hline & Arms & Trunk & Arms & Trunk & Arms & Trunk & Arms & Trunk \\
\hline & \multicolumn{2}{|c|}{ Before treatment } & \multicolumn{2}{|c|}{ 2 months } & \multicolumn{2}{|c|}{ 4 months } & \multicolumn{2}{|c|}{ 6 months } \\
\hline $\begin{array}{c}\text { Skin area } \\
\text { involved } \\
\text { Grade - A }\end{array}$ & 5 & 4 & 3 & 2 & 2 & 1 & 1 & 0 \\
\hline $\begin{array}{c}\text { Erythema } \\
\text { (Redness) }\end{array}$ & 3 & 3 & 1 & 1 & 1 & 0 & 0 & 0 \\
\hline $\begin{array}{c}\text { In duration } \\
\text { (Thickness) }\end{array}$ & 3 & 3 & 1 & 1 & 1 & 0 & 0 & 0 \\
\hline
\end{tabular}


Vishakha Shashikant Bindalkar et.al., Ayurvedic Management of Kitibha Kushta w.r.t. Guttate Psoriasis-A Single Case Study

\begin{tabular}{|c|c|c|c|c|c|c|c|c|}
\hline $\begin{array}{c}\text { Desquamati } \\
\text { on (scaling) } \\
\text { E, I, D- B }\end{array}$ & 3 & 3 & 0 & 0 & 0 & 0 & 0 & 0 \\
\hline Total- A x B & 45 & 36 & 6 & 4 & 4 & 0 & 0 & 0 \\
\hline $\begin{array}{c}\text { Total Body } \\
\text { Surface Area }\end{array}$ & $45 \times 0.2=9$ & $36 \times 0.3=10.8$ & $6 \times 0.2=1.2$ & $4 \times 0.3=1.2$ & $4 \times 0.2=0.8$ & $0 \times 0.3=0$ & $0 \times 0.2=0$ & $0 \times 0.3=0$ \\
\hline $\begin{array}{c}\text { Total PASI } \\
\text { Score- }\end{array}$ & \multicolumn{2}{|c|}{19.8} & \multicolumn{2}{|c|}{2.4} & 0.8 & \multicolumn{2}{|c|}{0} \\
\hline
\end{tabular}

Table no. 7: Showing Overall result of treatment

\begin{tabular}{|c|c|c|}
\hline & Before treatment & After treatment \\
\hline Erythma (Redness) & +++ & - \\
\hline In-duration (Thickness) & ++++ & - \\
\hline Desquamation (Scaling). & Hardness +++ & No itching \\
\hline Itching & ++++ & (
\end{tabular}

\section{Observation}
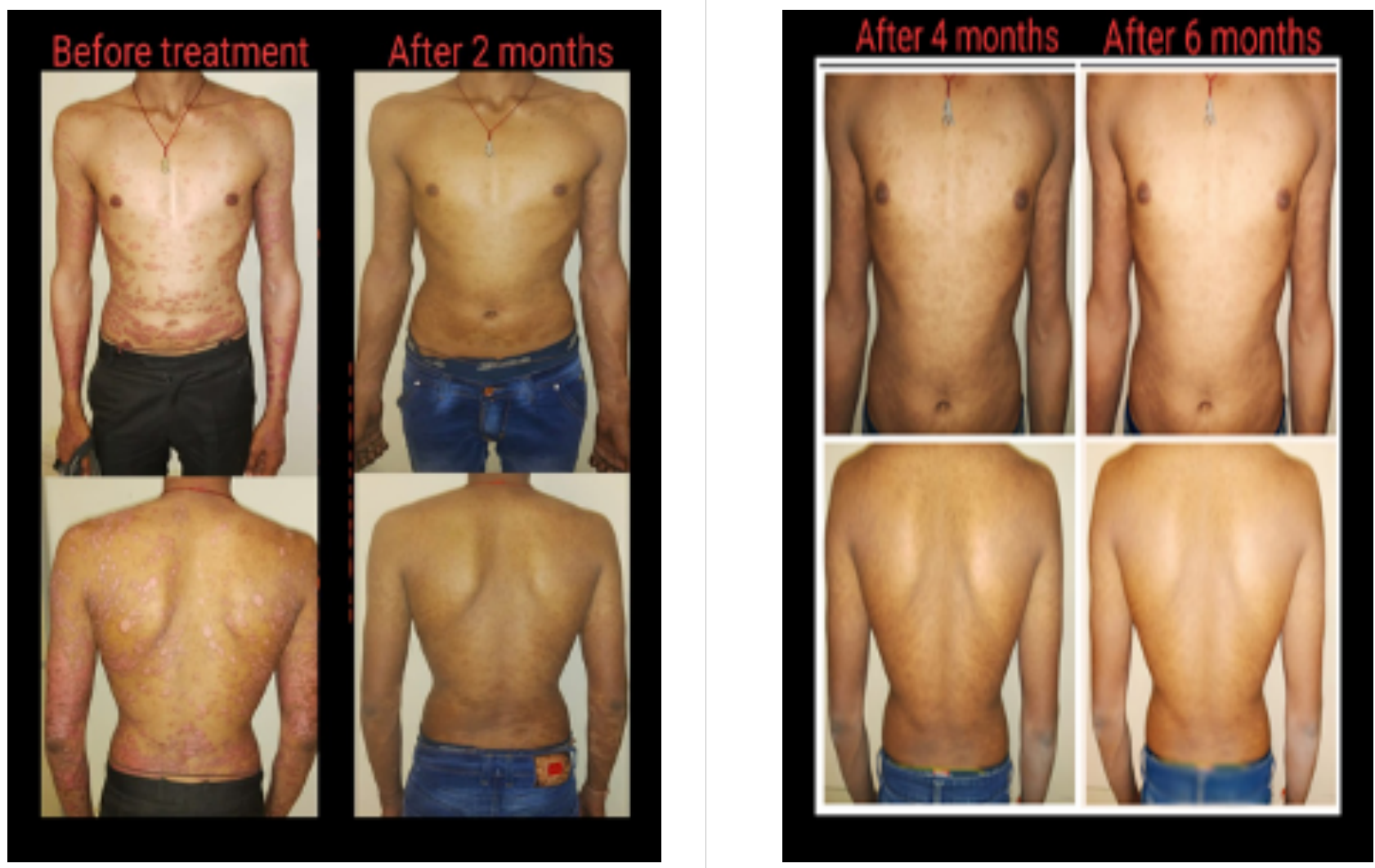

Picture no. 2: Showing before treatment, after 2 months, 4 months and 6 months follow up of treatment.

\section{Discussion}

Guttate psoriasis is a type of psoriasis that appears as little red blisters which is tear drop in shape. The small lesions over the upper trunk and proximal extremitie. In Ayurved as per its clinical features it can be correlated with the Kitibha kushtha. The predominant doshas in Kitibha kushtha are Vata and Pitta dosha. It is the vyadhi of raktavahastrotas, having sampraptighatak vata and kapha dosha, twak, lasika, rakta and mamsa. (10) The shodhan and shaman chikitsa are described in samhitas for the management of Kushtha. (11) Among the shodhan vaman is the best chikitsa for the kushtha followed by virechan karma as it eliminates the kapha and pitta sequentially from the body. In the present study shodhan, shaman and bahirparimarjan chikitsa was given to the patient. The treatment schedule was started by following the sequence of puvakarma, pradhan karma and paschyat karma. In purva karma, deepan - pachana dravya were given which are agnivardhak and amapachak. For that Trikatu churna was used, it was given for 3 days. After that Snehapan was given with the Panchatikta ghrit for 7 days. For the purposre of Abhyantar snehan, it causes the Vatashamana. For the Abhyanga the Marichyadi tail was used for the purpose of bahyasnehan, it reduces the dryness, provides the moisturization body, improves 
the blood circulation. Followed by sarwanga swedan it does the doshavilayana (liquefies the doshas) and brings them from Shakhas to Koshta to eliminate them. It also removes the strotorodha (obstraction in the strotas).

\section{Action of Snehapana - Panchatiktaghtrit}

The ingredients of Panchatikta are tikta rasa, ruksha and laghu guna. It acts mainly on kled, meda, lasika,rakta, pitta and kapha which helps in balancing the vitiated dosha and dhatu. It has properties like Deepan, Pachan, Strotoshodhak, Raktashodhak, Raktaprasadak, Kushtaghna, Kandughna and Varnya. (12) The Ghrit has lipophilic action helps to carry drugs to the target organs, it enters to its cellular level and delivers to mitochondria and nuclear membrane. It maintains the normal texture of skin.

\section{Action of Abhyanga with Marichyadi tail}

For the purpose of abhyanga or Bahyasnehana (external oleation) the Marichyadi tail is used. The most of dravyas of Marichyadi tail are have properties like katu, tikta, kashay rasa and ushna virya which does the shaman of Kapha and Vata dosha. Its snighdha guna reduces the rukshatva, kharatva and parushata. It has properties like Raktashodhan, Kushtaghna and Kandughna. The nature of tail is Sukshmagamitva means it helps drugs to go into the minute channels and does the proper absorption. The Kashay rasa of these dravyas helps to reduce the Kleda. (13) Marichyadi tail has antiseptic, antifungal, anti-inflammatory, antimmuno modulatory property. The Marichyadi tail is effective in the Symptoms of kitibha kushtha due to these properties.

\section{Action of Vaman karma}

Vaman does the elimination of the prakupit doshas mainly kapha and pitta from the koshtha. The vamanopaga dravyas, such as Madanphal churna, Vacha churna, Pippali churna, Saindhav, Madhu, Yashtimadhu phanta having properties like ushna, Tikshna, Vyavayi and Vikasi it enhances the absorption rate and helps to reach at Hriday. It moves from hriday to the Dhamani to all Sthul and Sukshma strotas. It acts on the microcellular level which removes all the toxins from the body. There is the predominance of the Agni and Vayu mahabhutas. Vamak dravyas has the urdhwabhagahar prabhav which causes the elimination of doshas from the upward direction i.e, from the mouth. This therapy is very effective for the elimination of aggravated doshas.

\section{Action of Virechan karma}

The Virechan dravyas which are having properties like Ushna, Tikshna, Sukshma, Vyavayi,

Vikasi it reaches to the heart due to their potency it enters into the all over dhamanis and circulates throughout the sthula and sukshma strotas. Then it does the liquefaction of the dosha sanghat due to its Agneya guna. This Doshasanghat gets chhinnabhinna and circulates through out the strotas and didn't get sticks any where because the Snehan was done in the purvakarma, as like honey not sticks to the vessel which is coated by oil. This doshasanghat passes through the minute capillaries and moves towards the koshtha and ultimately reaches to the amashay. The virechan drug has the predominance of the Jala and Prithvi mahabhuta, so it acts as a Adhobhagahara prabhav. It does the elimination of the vitiated dosha from the guda marga. (14)

\section{Action of Arogyavardhini vati}

According to the Rasaratnasamucchya, Bhaishajyaratnavali and Bharatbhaishajyaratnakar it has the property like Kushthanashak (Alleviates all skin disorders), Kandughna (alleviates itching), Deepan (appetizer), Pachan (digestive), Malasuddhikari (cleanses waste material from the body), Sarvarogaprashamani (alleviates all disorders from body), Raktavardhak (purifies the blood). It contains, Haritaki (Terminalia chebula Retz.), Bibhitaki (Terminalia bellerica Roxb.), Amalaki (Embelica officinalis Gaertn.), Suddha shilajatu (Asphaltum), Suddha guggul (Commiphora wightii), errand (ricinus communis), Katuka (Picrorrhiza kurroa Royle ex Benth), Nimba (Azadirachta indica A. Juss.), Suddha Parad (purified mercury), Suddha Gandhak (purified sulphur), Lauha bhasma, Abhrak bhasma, Tamra bhasma.(15) It acts as antioxidant, removes the toxins from the body. (16)

\section{Action of Manibhadra guda}

Manibhadra guda is used as kushtaghna, krumighna, kandughna. It contains Vidanga (Embelia ribes Burm F.), Amalaki (Embelica officinalis Gaertn.), Haritaki (terminalia chebula Retz.), Trivrut (Operculina turpethum linn.) and Guda (Jaggery).It is indicated in disease like Kushtha (Skin diseases), Kasa (Cough, bronchitis), Shwas (Asthma), Arsha (piles), Krumi (Intestinal worms), Pleeha vikar (spleen related diseases), Udar roga (regulates the bowel movements). (17)

\section{Action of Gandhak Rasayan}

Gandhak rasayan acts as Kushtaghna, Kandughna, Dahaprashaman, Raktashodhak, Vranaropak, Twachya, Krumighna. It is mainly indicated in Kushta roga. It possess the property like antibacterial, antiviral and antimicrobial. (18) In all types of skin disorders the purified sulphur is useful for the treatment. It reduces the itching and infection. Beneficial for the skin complexion and improves digestion. In skin diseases it can be used both internally and externally for the treatment.

\section{Action of Raktashodhak vati}

Raktashodhak vati is used in the treatment of skin disease like skin rash, eczema, psoriasis and acne. It contains Manjishtha (Rubia cordifolia L.), Shuddha Gandhak (Purified Sulphur), Anantamool (Hemidesmus indicus L. R.BR.). It purifies the blood, therefore helpful in the treatment of skin disorders. It improves the complexion of the skin. (19) 


\section{Action of Vetapalai oil}

Vetapalai oil having Kushthaghna, anti-inflammatory, antibacterial, antiviral, antifungal, anti-microbial, antioxidant properties. It is indicated in treatment of skin disease, itching, pruritus, psoriasis. It improves the skin complexion, relieves pain and efficient in wound healing. All the contents are Vata, Pitta, Kapha Shamak (pacifies the Tridosha), Twachya (which improves complexion). It moisturizes and soothes the skin. (20)

\section{Action of Atrisor cream}

Atrisor cream contains Jivanti (Holestemma ada- kodein Schult.), Manjishtha (Rubia cordifolia L.), Haridra (Curcuma longa L.), Streekutaja (Wrightia tinctoria Roxb.R.Br.), Narikela (Cocos nucifera L.) and Tuvarak taila (Hydnocarpus wightianus Blume.). It is an antipsoriatic topical offering quick and complete relief from inflammation, itching and irritation associated with psoriatic lesion. Its emollient action brings back normal skin texture and makes it soft and supple. Atrisor cream is indicated in all types of psoriasis. (21)

\section{Action of 777 oil}

777 oil is commonly priscribed for psoriasis. Shweta indrajao (Wrightia tinctoria Roxb. R. Br.) and Narikela (Cocos nucifera L.) both have soothing effect and acts as moisturizer. In psoriasis, skin cells grow rapidly and extra cells result in thickening of the skin, itching, dryness, red patches and silvery scales. Both ingredients reduce dryness, itching, redness and inflammation. It also softening the skin and reduces thickness. It exerts the medicinal properties like Antiinflammatory, Antipuritics, Antiulcerogenic, and Demulcent. It is indicated in all types of psoriasis, Dry skin, dandruff, fungal infectin, fissure foot. (22)

\section{Action of Atrisor moisturizer}

Atrisor moisturizer contains Narikel tail (Cocos nucifera L.), Nimba (Azadirachta indica A Juss.), Haridra (Curcuma longa L.), Manjishtha (Rubia cordifolia L.) and shweta indrajao (Wrightia tinctoria Roxb. R. Br.). It reduces the inflammation of the skin and itching associated with psoriasis, this relieving itchy, flaky and dry skin. Atrisor moisturizer restores moisture in the skin and helps in keeping the skin soft and supple. It prevents further dryness and exacerbation of the lesion. (23)

The Erythema (Redness), In-duration (Thickness), Desquamation (Scaling) and Itching of the lesion was very severe before treatment, but the improvement was seen after the treatment of patient with Shodhan, Shaman and Bahirparimarjan chikitsa. There is significant result in the Erythema (Redness), In-duration (Thickness), Desquamation (scaling) and Itching. The PASI scale was considered. Before treatment the PASI score was 19.8. After 2 months it was 2.4 , after 4 months it was 0.8 , after 6 months it was reduced to 0 . In the present case study the patient got the $90 \%$ relief in the symptoms after following the Shodhan (Vaman and Virechan), Shaman (Internal medications) and Bahirparimarjan chikitsa.

\section{Conclusion}

The Guttate Psoriasis can be correlated with Kitibha Kushtha, which is a type of Kshudra Kushtha. From the above case study it can be concluded that the Kitibha Kushtha can be successfully treated with the Shodhan (Vaman and Virechan), Shaman (Internal medications) and Bahirparimarjan Chikitsa (External application). As it is a single case study, it is recommended to conduct the research study on more number of patients to prove the effectiveness of the treatment modalities.

\section{Reference}

1. Freedberg, et al, ftzpatrick's Dermatology in General medicine. $6^{\text {th }}$ ed. MC Graw Hill; 2003. ISBN 0-7-138076-0.

2. James William, Berger, Timothy, Elston Drick, Andrew's Diseases of the skin Clinical Dermatology. $10^{\text {th }}$ ed. Saunders; 2005. ISBN 0-7216-2921-0.

3. Feldmen SR, Clark AR, Treatment of Psoriasis; An Algorith-Based Approach for Primary Care Physician. 2000, Retrieved 30 mar 2011. Am Fam Physician. 61: 725-33, 736.

4. https://www.healthengine.com.all/info/psoriasissubtypes\#c4 date 01-01-2020 time 12.15

5. Shukla and Ravi Dutt Tripathi, Agnivesh, Charak samhita, Chakrapani Commentary, Indriyasthan Chapter 9, shloka 8, Varanasi:Chowkhamba Sanskrit Pratishthan 2009.

6. Shukla and Ravi Dutt Tripathi, Agnivesh, Charak samhita, Chakrapani Commentary, Nidansthan Chapter 5, shloka 4, Varanasi:Chowkhamba Sanskrit Pratishthan 2009.

7. Shukla and Ravi Dutt Tripathi, Agnivesh, Charak samhita, Chakrapani Commentary, Chikitsasthan Chapter 7, shloka 22, editors, Varanasi: Chowkhamba Sanskrit Pratishthan 2013.

8. Tripathi Bramhananda, Ashtanga Hridaya of Vagbhatta, Sutrasthana, 17/22, Chaukhamba Sanskrit Pratishthana, Delhi, 2015, p. 216.

9. Vaghbhatacharya, ashtanghridaya, sutrasthan, snehavidhiadhaya. 13/45 edited by Dr. Annamoreshvara kunnte, edition. Reprint 2010 chaukamba sansthana Varanasi, p, 249.

10. Shukla and Ravi Dutt Tripathi Agnivesha, Charak Samhita, Chakrapani Commentary, Chikitsasthan chapter 21, shloka 15, editors, Varanasi: Chowkhamba Sanskrit Pratishthan; 2013.

11. Shukla and Ravi Dutt Tripathi, Agnivesh, Charak samhita, Chakrapani Commentary, Chikitsasthan Chapter 7, shloka 39, editors, Varanasi: Chowkhamba Sanskrit Pratishthan 2013.

12. Bramhashankar Mishra, Bhaishajya Ratnavali, VolIII edition 1st, 54/257- 260, New Delhi: Chaukhamba Sanskrit Bhavan; 2006. p.82

13. Bramhashankar Mishra, Bhaishajya Ratnavali,VolIII edition 1st, 54/301- 302, New Delhi: Chaukhamba Sanskrit Bhavan; 2006. p.92.

14. Shukla and Ravi DuttTripathi Agnivesha, CharakSamhita, Chakrapani Commentary, 
Kalpasthan chapter 1, shloka 5, editors, Varanasi: Chowkhamba Sanskrit Pratishthan; 2013.

15. Anonymous. Ayurved Formulary of India. Controller of publications. Ministry of Health and Family Welfare, Government of India, New Delhi.2005.

16. Santosh pal et al. Arogyavardhini Vati: A theoritical analysis, JSIR 2016; 5(6): 225-227.

17. K. R. Srikantha Murthy, Astanga Hridaya of Vagbhat's, Vol II Chikitsasthan chapter 19, shloka 31-32, editors, Varanasi: Chaukhamba Krishnadas Academy; 2006. P.477.

18. SaokarR,et al, Screening of Antibacterial and Antifungal Activity of Gandhaka Rasayana- an Ayurvedic Formulation, International Journal of Recent Trends in Science And Technology, ISSN
2277-2812 E-ISSN 2249-8109, Volume 8, Issue 2, 2013 pp 134-137).

19. https://www.myupchar.com/en/medicine/ baidyanath-raktashodhak-tablets-p36777335 date 03-01-2020 time 13.10

20. https://www.amazon.ae/Dr-stanles-PsoreaseEffective-Psoriasis-treatment/dp/B07B3T2c95 date 03-01-2020 time 14.00

21. https://onlineayurvedaworld.com/atrisortopical-50gm-atrimed-discount-10 date 03-01-2020 time 14.30

22.https://medium.com/@drjrkresearch/777oil-3e0aae60fa53 date 03-01-2020 time 15.20

23. https://www.ayurvedaforall.com/atrisormoisturizer.html date 03-01-2020 time 15.45 